uncertain until nephrocalcinosis was diagnosed by the regional nephrology unit.

\section{CONCLUSIONS}

Screening with ultrasonography in a low risk population can detect many fetal malformations and may reduce perinatal mortality. The demonstration of a normal fetus can be reassuring to the parents but, as we have discussed above, there are several limitations to such a screening programme, which is available only to women who book early enough. High levels of anxiety can be caused, not only with false positive diagnoses but also after identifying minor (possibly normal) variants. More data need to be collected in low risk populations concerning these normal variants together with the long term prognosis associated with many ultrasonographic findings so that we may counsel parents more accurately.

We thank Tricia Jones, midwife counsellor, for her help in collecting the data. LSC was funded by a Medical Research Council training fellowship.

1 Ash P, Vennart J, Carter CO. The incidence of hereditary disease in man. Lancet 1977; i:849-5

2 Chitty LS, Winter RM. Perinatal mortality in different ethnic groups. Arch Dis Child 1989;64:1036-41.
3 Nicolaides $\mathrm{KH}$, Campell S. Diagnosis and management of fetal malformations. Baillieres Clin Obstet Gynaecol 1987;1:591-622.

4 Persson PH, Kullander S. Longterm experience of general ultrasound screening in pregnancy. Am $\mathcal{F}$ Obstet Gynecol 1987;146:942-7.

5 Campbell S, Smith P. Routine screening for congenital abnormalities by ultrasound. In: Rodeck CR, Nicolaides KN, eds. Prenatal Diagnosis. Proceedings of the 11th study group of the Royal College of Obstetricians and Gynaecologists. London: RCOG, 1983:325-30.

6 Levi S, Crouzet P, Schaaps JP, Defoort P, Coulon P, Buelens P, et al. Ultrasound screening for fetal malformations. Lancet 1989;i:678.

7 Rosendahl K, Kivinen S. Antenatal detection of congenital malformations by routine ultrasonography. Obstet Gynecol 1989;73:947-51.

8 Saari-Kemppainen A, Karialainen O, Ylostalo P, Heinonen OP. Ultrasound screening and perinatal mortality: controlled trial of systematic one-stage screening in pregnan Lancet 1990;336:387-91.

9 Jones LJ. Smith's recognisable patterns of human malformation. 4th ed. Philadelphia: W B Saunders, 1988:662-81.

10 De Wals P, Mastroiacovo P, Weatherall JAC, Lechat MF. Eurocat guide. Louvain: Catholic University, 1984:65.

11 Gardner MJ, Altman DG. Statistics with confidence. London: British Medical Journal, 1989:28-9.

12 Benacerraf BR. Fetal hydrocephalus: diagnosis and significance. Radiology 988;169:858-9.

13 Benacerraf BR, Adzick NS. Fetal diaphragmatic hernia: ultrasound diagnosis and clinical outcome in 19 cases. Am 7 Obstet Gynecol 1987;156:573-6.

14 Benacerraf BR. Prenatal sonography of autosomal trisomies. Ultrasound in Obstetrics and Gynaecology 1991;1:66-75.

15 Chitty LS, Chudleigh P, Pembrey ME, Campbell S. Multicentre study of antenatal calyceal dilatation detected by ultrasound. Lancet 1990;336:875.

16 Chitty LS, Griffin DR, Johnson P, Neales K. The differential diagnosis of enlarged hyperechogenic kidneys with normal or increased liquor volume: report of five cases and review of the literature. Ultrasound in Obstetrics and Gynecology 1991;1:115-21.
Respiratory Medicine Unit, City Hospital, Nottingham NG5 1PB

Rosalind Hill, MPHIL research assistant Jacqueline Williams, BA, clerical assistant John Britton, MD, lecturer Anne Tattersfield, MD, professor

Correspondence to: Ms Hill.

BMF 1991;303:1169-74

\title{
Can morbidity associated with untreated asthma in primary school children be reduced?: a controlled intervention study
}

\author{
Rosalind Hill, Jacqueline Williams, John Britton, Anne Tattersfield
}

Abstract

Objective-To determine whether an intervention programme based on existing school and community resources can reduce school absence and improve participation in games lessons and sport in children with unrecognised or undertreated asthma.

Design-Parallel group controlled intervention study.

Setting-102 primary schools in Nottingham: 49 were randomised to receive the intervention and 53 to be control schools.

Subjects-All children aged 5 to 10 years with parent reported absence from school because of wheezing in the previous year and taking no treatment or $\beta$ agonists only.

Interventions-Children with asthma were referred to their general practitioner for assessment of symptoms and treatment. Teachers were given education on asthma by the school nurse in 44 of the 49 intervention schools.

Main outcome measures-Changes in school absence and missed games and swimming lessons because of wheezing, and schools' policy towards management of asthma in school.

Results - Of 17432 children screened, 451 met the entry criteria -228 in intervention schools and 223 in control schools. $152(67 \%)$ children in intervention schools visited their general practitioner, of whom $39(26 \%)$ were given a new diagnosis of asthma and 58 $(38 \%)$ had treatment for asthma increased or changed. Over the next academic year mean (SE) parent reported school absence due to wheezing fell significantly, but to a similar extent, in both intervention and control schools $(0.82(0.11)$ and $1.09(0.21)$ weeks respectively). There was little change in school recorded absence or participation in games lessons and swimming lessons in either group. At the end of the study intervention schools were more likely to have improved aspects of management of asthma in school.

Conclusion-The intervention resulted in a majority of children being assessed by their general practitioner and improved teachers' understanding and management of asthma, but it did not result in any appreciable reduction in morbidity.

\section{Introduction}

Morbidity attributed to underdiagnosis and undertreatment of asthma in schoolchildren ${ }^{1.9}$ is common and should be preventable. During the early 1980s two uncontrolled studies in Newcastle found a considerable reduction in school absence because of wheezing after children with wheezing had been assessed and, if appropriate, treated for asthma. ${ }^{47}$ Since then the recognition of asthma and prescribing of drugs for asthma in children has increased greatly, ${ }^{10} 1^{\circ}$ but children continue to miss school because of apparently untreated or undertreated wheezing. ${ }^{10}$

To determine whether improvements can still be achieved in school attendance and participation in school activities of children with asthma and management of asthma in schools we conducted a randomised, controlled study of the effect of a simple intervention programme in 102 primary schools in Nottingham. The intervention was designed specifically to use health care resources already available to most schools so that if successful it would be suitable for more widespread implementation. The intervention entailed medical appraisal of children suspected of having undertreated asthma and, as children spend much of their time at school and staff may not be familiar with asthma and its treatment, ${ }^{12} 13$ it included a programme of education for teachers about asthma. 


\section{Methods}

The 102 primary schools in the Nottingham postcode area that were not included in a random sample for a previous study ${ }^{10}$ were invited to participate. A screening questionnaire asking about wheezing, use of drugs, and school absence because of wheezing was sent to parents of all children aged 5 to 10 years in these schools in May 1988. Urdu translations were provided where necessary. From the responses to the questionnaire we identified children who were particularly likely to have undiagnosed or undertreated asthma. They included all children who had been absent from school because of wheezing at any time in the past year and who were taking no treatment for asthma; al children who had lost more than five days of schooling because of wheezing and were not taking regular prophylactic drugs for asthma; and all children who had lost more than 10 days' schooling because of wheezing, irrespective of treatment (only three of these children were receiving treatment other than with $\mathbf{a}_{2}$ agonist). Children who had attended a hospital outpatient clinic for asthma in the six months before the questionnaire were excluded.

As the intervention involved school nurses, who work in teams covering more than one school, schools were randomised to receive the intervention or to be a control according to their school nurse team.

\section{INTERVENTION}

\section{General practitioner assessment}

Parents of children with asthma in a school receiving the intervention were sent a letter in June or July 1988 asking them to take their child to see their family doctor for assessment. General practitioners were notified and asked to review the child's diagnosis and treatment according to guidelines for the diagnosis and management of asthma in children that we compiled with advice from two paediatricians and a general practitioner. The guidelines emphasised the use of peak flow meters for diagnosis and assessment of symptoms and the value of prophylaxis and of giving drugs by the inhaled route.

\section{School nurse teaching sessions}

School nurses in the intervention schools were invited to an asthma study afternoon in September 1988. The nurses were given teaching materials, including the text of a 30 minute talk on asthma and visual aids, and asked to hold a teaching session for teachers in their schools during the next school term. They were also asked to identify children who brought inhalers to school and to check that they were using them correctly and appropriately.

\section{ASSESSMENT}

Outcome of visits to general practitioners

General practitioners and parents were asked to complete a brief questionnaire after the child had been seen to summarise any change in diagnosis or treatment and any other advice given by the general practitioner.

\section{Changes in school attendance and participation}

Questionnaire for parents-Parents were asked to estimate the number of days lost from school, the number of games lessons and swimming lessons missed because of wheezing, and details of diagnosis and treatment during the previous school year in May 1988 and again in May 1989. Absence from school was measured in school weeks (five days). Children were grouped according to how many games lessons and swimming lessons they had missed (see table I).

Class registers of school attendance-Absence from school for each term (for all causes) was taken from class registers for the school years $1987-8$ and 1988-9. Data from matched non-wheezy children (the child whose name was on the class register after each study child) were used to provide an estimate of usual school absence for the year 1987-8.

Questionnaire for teachers-Teachers were asked to record the number of games lessons and swimming lessons, school outings, and outside play sessions missed by the child in the summer term preceding the intervention and for each term over the study year at the end of each term.

\section{Changes in school practices and teachers' knowledge}

Questionnaire for head teachers-Head teachers were asked about the number of children before and after the study taking drugs for asthma to school, policies towards children taking drugs for asthma, and parents' communication with the school regarding asthma.

Questionnaire for parents-All parents who reported that their child took drugs for asthma in May 1988 were asked about the child's access to such drugs in school and before sport one year later.

Questionnaire for teachers - Teachers' experience and knowledge of asthma was assessed by a questionnaire and multiple choice test at the end of the study.

Questionnaire on asthma teaching sessions-Nurses and teachers were asked to comment on the asthma teaching sessions.

\section{STATISTICAL ANALYSIS}

The power of the study was estimated from knowledge of the time lost from school by wheezy children in Nottingham in $1985^{10}$; the sample size of 150 children in each group was adequate to provide $95 \%$ power to detect a difference of two days $(0.4$ weeks $)$ in school absence because of wheezing over the previous school year at a $5 \%$ significance level. The statistical package for social sciences (SPSS) was used to provide descrip-

TABLE I-Details of the 451 children in intervention and control schools for the year before the study. Figures are numbers (percentages) of children unless otherwise stated

\begin{tabular}{|c|c|c|}
\hline & $\begin{array}{c}\text { Intervention } \\
\text { group } \\
(\mathbf{n}=228) \\
\text { No }(\%)\end{array}$ & $\begin{array}{c}\text { Control group } \\
(\mathbf{n}=223) \\
\text { No }(\%)\end{array}$ \\
\hline \multicolumn{3}{|l|}{ Sex: } \\
\hline Male & $130(57)$ & $104(47)$ \\
\hline Female & $98(43)$ & $119(53)$ \\
\hline Asthma diagnosed & $92(40)$ & $88(39)$ \\
\hline Currently using drugs for asthma & $51(22)$ & $50(22)$ \\
\hline \multicolumn{3}{|l|}{ No of wheezing episodes in previous year: } \\
\hline $1-4$ & $152(67)$ & $136(61)$ \\
\hline $5-10$ & $40(18)$ & $43(19)$ \\
\hline$>10$ & $25(11)$ & $31(14)$ \\
\hline Unspecified & $11(5)$ & $13(6)$ \\
\hline \multicolumn{3}{|c|}{$\begin{array}{l}\text { No of weeks absent from school because of wheezing } \\
\text { in previous year (from parent report): } \\
0\end{array}$} \\
\hline 1 & $88(39)$ & $77(35)$ \\
\hline 2 & $80(35)$ & $77(35)$ \\
\hline 3 & $32(14)$ & $33(15)$ \\
\hline 4 & $17(8)$ & $20(9)$ \\
\hline 5 & $11(5)$ & $16(7)$ \\
\hline Mean (SE) No of weeks & $1.55(0.07)$ & $1.69(0.08)$ \\
\hline $\begin{array}{l}\text { Mean (SE) No of days' absence per term } \\
\text { because of any cause (from class registers) }\end{array}$ & $5 \cdot 57(0 \cdot 28)$ & $6.01(0.34)$ \\
\hline \multicolumn{3}{|l|}{$\begin{array}{l}\text { No of games lessons missed in previous year } \\
\text { (from parent report) }{ }^{\star} \text { : }\end{array}$} \\
\hline 0 (Category 1$)$ & $152(67)$ & $148(66)$ \\
\hline 1-2 (Categor & $37(16)$ & $27(12)$ \\
\hline 3-5 (Category 3) & $25(11)$ & $37(17)$ \\
\hline 6-10 (Category 4) & $11(5)$ & $5(2)$ \\
\hline$>10$ (Category 5$)$ & $3(1)$ & $6(3)$ \\
\hline Mean (SE) category & $1.57(0.07)$ & $1.63(0.07)$ \\
\hline \multicolumn{3}{|l|}{$\begin{array}{l}\text { No of missed swimming lessons in previous } \\
\text { year (from parent report): }\end{array}$} \\
\hline $0($ Category 1$)$ & $84(37)$ & $64(34)$ \\
\hline 1-2 (Category 2) & $62(27)$ & $72(32)$ \\
\hline 3-5 (Category 3$)$ & $31(14)$ & $41(18)$ \\
\hline 6-10 (Category 4$)$ & $12(3)$ & $14(6)$ \\
\hline No swimming & $39(17)$ & $32(14)$ \\
\hline Mean (SE) category & $1.85(0.06)$ & $2.03(0.06)$ \\
\hline
\end{tabular}

$\star^{\star}$ Refers to lessons lost when in school 
tive statistics and for baseline comparisons, by using Students' $t$ test and $\chi^{2}$ analyses. ${ }^{14}$ Changes in measures of morbidity between groups were compared by analysis of variance by using the generalised linear interactive modelling (GLIM) program. ${ }^{\text {is }}$ Inspection of the distributions of changes in the variables between groups showed no appreciable departures from normality, so untransformed means and error distributions were used for all comparisons between groups. Where possible the analyses dealt with changes over the academic years. As complete data from school attendance registers were not provided for all children for all three school terms these data were analysed as averages for each term. A conversion factor of 1.7 was used to compare school absence measured in weeks each year (from parent reports) with absence in days each term (from school registers).

\section{Results}

RESPONSE RATES, RESPONDENTS, AND COMPLIANCE

All of the 102 schools invited to take part in the study agreed to do so.

\section{The screening questionnaire}

Of 17432 screening questionnaires sent to parents, replies were received for $13585(77 \cdot 9 \%)$ children. Of these, $1738(12.8 \%)$ reported wheezing in the past year, $1201(8.9 \%)$ a diagnosis of asthma, and 1026 ( $7 \cdot 6 \%)$ absence from school because of wheezing in the previous year.

\section{The study group}

In all, 451 children fulfilled the entry criteria for the study. The mean (SE) parent reported absence from school because of wheezing in these children in the previous year was $1.62(1.17)$ weeks $(2.7$ days each term). Mean absence due to all causes recorded in school registers for these children was twice as high at $5.73(0.26)$ days each term $(3.4$ weeks each year); this was $1.89(0.24)$ days each term more than matched non-wheezy children $(\mathrm{p}<0.001$, data provided for $69 \%$ of matched children).

Forty nine schools from 15 school nurse teams were randomised to receive the intervention and 53 schools from 17 nurse teams to be controls. As a result 228 of the 451 children were allocated to the intervention group and 223 to the control group. There was little difference between the two groups in the year before

TABLE II -Changes in morbidity associated with wheezing from 1988 (before intervention) to 1989 (after intervention). Comparison of control children with all intervention children, those who attended the general practitioner, and those for whom the general practitioner changed or introduced treatment for asthma

\begin{tabular}{|c|c|c|c|c|}
\hline & \multicolumn{3}{|c|}{ Intervention group } & \multirow[b]{2}{*}{ Control group } \\
\hline & Whole group & $\begin{array}{l}\text { Those who visited } \\
\text { their doctor }\end{array}$ & $\begin{array}{l}\text { Those whose } \\
\text { treatment was } \\
\text { changed }\end{array}$ & \\
\hline \multicolumn{5}{|c|}{ School absence because of wheeze (weeks) $\dagger$} \\
\hline No of children & 145 & 126 & 49 & \multirow{3}{*}{${ }^{147} 1.09(0.21)^{\star}$} \\
\hline Mean (SE) decrease & $0.82(0.11)^{\star}$ & $0.58(0.17)$ & $0.58(0.25)$ & \\
\hline $95 \%$ Confidence interval & $(-0.82$ to 0.26$)$ & $(-1.1$ to 0.08$)$ & $(-1 \cdot 2$ to $0 \cdot 19)$ & \\
\hline \multicolumn{5}{|c|}{ School absence due to all causes $($ day/term $) \ddagger$} \\
\hline No of children & & 128 & 51 & \multirow{3}{*}{$\begin{array}{l}193 \\
-0.22(0.73)\end{array}$} \\
\hline Mean (SE) decrease & $0 \cdot 14(0 \cdot 49)$ & $0.49(0 \cdot 4)$ & $0.44(0.55)$ & \\
\hline $95 \%$ Confidence interval & $(-1.53$ to 2.25$)$ & $(-1 \cdot 16$ to $2 \cdot 58)$ & $(-1.31$ to 2.63$)$ & \\
\hline \multicolumn{5}{|c|}{ Missed games lessons (category) $₫$} \\
\hline No of children & 145 & 126 & 47 & \multirow{3}{*}{$\begin{array}{l}147 \\
0 \cdot 01(0 \cdot 15)\end{array}$} \\
\hline Mean $(\mathrm{SE})$ decrease & $0.08(0 \cdot 11)$ & $0.09(0.11)$ & $0 \cdot 11(0 \cdot 15)$ & \\
\hline $95 \%$ Confidence interval & $(-0.34$ to 0.48$)$ & $(-0.33$ to 0.49$)$ & $(-0.19$ to 0.39$)$ & \\
\hline \multicolumn{5}{|c|}{ Missed swimming lessons (category) } \\
\hline No of children & 107 & 86 & 40 & \multirow{2}{*}{$\begin{array}{l}106 \\
0 \cdot 29(0 \cdot 16)\end{array}$} \\
\hline $\begin{array}{l}\text { Mean (SE) decrease } \\
95 \% \text { Confidence interval }\end{array}$ & $\begin{array}{r}0.25(0.23) \\
(-0.6 \text { to } 0.52)\end{array}$ & $\begin{array}{c}0.3(0.25) \\
(-0.58 \text { to } 0.6)\end{array}$ & $\begin{array}{c}0.5(0.36) \\
(-0.52 \text { to } 0.94)\end{array}$ & \\
\hline
\end{tabular}

\section{${ }^{\star} \mathrm{p}<0.05$.}

†From parent reports.

From school registers.

Mean decrease in category. For the five categories see table I.

$\|$ Mean decrease in category. For the four categories see table I. the study with respect to frequency of wheezing, diagnosis, drugs, absence from school, and the number of games lessons and swimming lessons missed (table I). The ratio of boys to girls in the two groups differed slightly but not significantly.

\section{Compliance}

Completion of study-Of the 451 children, 296 were successfully followed up over the next year (fig 1).

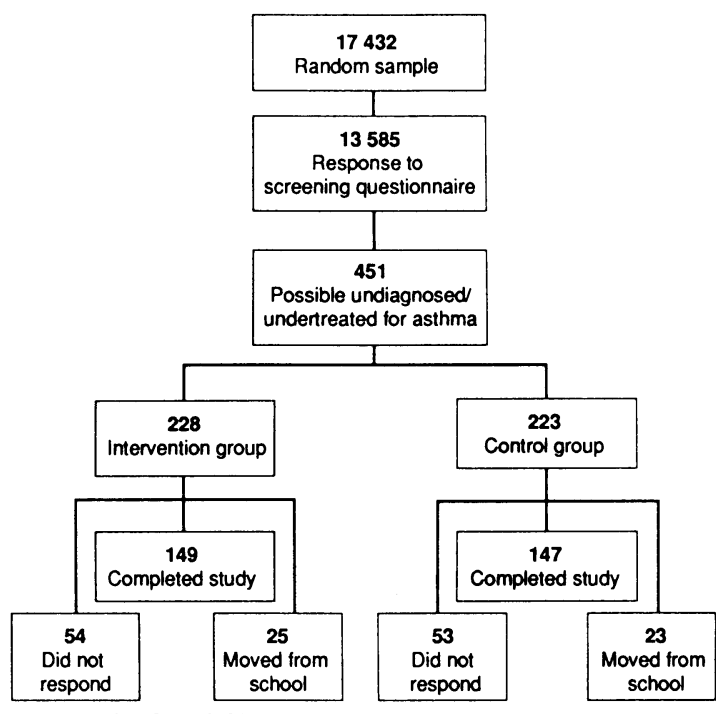

FIG 1-Number of children entered into and completing study

Respondents and non-respondents did not differ significantly in terms of sex, age, frequency of symptoms, use of drugs, and morbidity associated with wheezing. Almost identical proportions were followed up in intervention and control groups.

General practitioner assessment-Of the 228 children in the intervention group, $152(67 \%)$ consulted their doctor as requested, $20(9 \%)$ declined to do so, and 56 $(25 \%)$ failed to respond to this or any further request (fig 2).

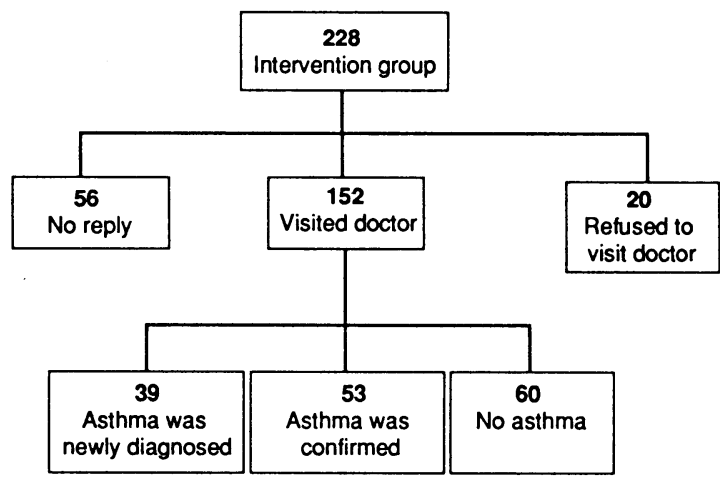

FIG 2-Number of children in intervention schools taken to family doctor

School nurse teaching session-Sixty three teaching sessions were delivered in 44 intervention schools. The sessions lasted up to one hour and were held during lunch breaks or after school. Nurses checked the inhaler technique of two thirds of the children known to take inhalers to school:

\section{OUTCOME OF VISIT TO GENERAL PRACTITIONER}

Of the 152 children who visited their general practitioner, $39(26 \%)$ were given a new diagnosis of asthma, $60(39 \%)$ were told they did not have asthma, and 53 (35\%) had a diagnosis of asthma confirmed (fig 2). Treatment for asthma was started in 20 children, 22 children had prophylactic drugs (inhaled steroid or sodium cromoglycate) added to their previous treatment, and the route of delivery of $\beta$ agonists and the 
mode of delivery was changed for $16(11 \%)$ children. Antibiotics were prescribed for 16 and antihistamines for five. Peak flow was recorded for 36 (24\%) children; seven were referred to a hospital specialist.

\section{EFFECT OF THE INTERVENTION}

\section{School attendance and participation in activities}

There was a pronounced and significant reduction in parent reported absence from school because of wheezing in 1988-9 compared with the previous school year, but this occurred to a similar extent in children in both intervention and control schools (mean (SE) changes $0.82(0.11)$ and $1.09(0.21)$ weeks respectively, table II). Similar results were also seen in the children reported as losing more than two weeks from school in the initial survey (76 in intervention schools and 78 in control schools), with parent reported absence decreasing from 3.7 weeks each year in both groups by a mean (SE) of $1.6(0.3)$ weeks in the intervention schools and $1.8(0.23)$ weeks in the control schools. There was, however, little change in absence due to all causes obtained from school registers for either group of children over the study period (table II), and no significant changes in participation in the school activities assessed (table III). Nor was there any measurable

TABLE III - Number (percentage of respondents) of children missing school activities because of wheezing in the previous term (from teachers' reports) in intervention and control schools

\begin{tabular}{|c|c|c|c|c|}
\hline & \multirow{2}{*}{$\frac{\begin{array}{c}\text { Before } \\
\text { intervention }\end{array}}{\begin{array}{c}\text { Summer } \\
1988\end{array}}$} & \multicolumn{3}{|c|}{ Intervention year } \\
\hline & & $\begin{array}{l}\text { Winter } \\
1988\end{array}$ & $\begin{array}{l}\text { Spring } \\
1989\end{array}$ & $\begin{array}{c}\text { Summer } \\
1989\end{array}$ \\
\hline \multicolumn{5}{|c|}{$\begin{array}{l}\text { No }(\%) \text { of children for whom a } \\
\text { reply was obtained: }\end{array}$} \\
\hline Intervention & $178(78)$ & $165(72)$ & $179(79)$ & $171(75)$ \\
\hline Control & $154(69)$ & $167(75)$ & $151(68)$ & $137(61)$ \\
\hline \multicolumn{5}{|c|}{ Missing school outings: } \\
\hline Intervention & $4(2)$ & $6(4)$ & $1(<1)$ & $1(<1)$ \\
\hline Control & $6(4)$ & $3(2)$ & $1(<1)$ & \\
\hline \multicolumn{5}{|c|}{ Missing swimming lessons: } \\
\hline Intervention & $22(12)$ & $18(11)$ & $30(17)$ & $20(12)$ \\
\hline Control & $17(11)$ & $34(20)$ & $23(15)$ & $10(7)$ \\
\hline \multicolumn{5}{|c|}{ Missing games lessons: } \\
\hline Intervention & $9(5)$ & $17(10)$ & $19(11)$ & $16(9)$ \\
\hline Control & $7(5)$ & $21(13)$ & $7(5)$ & $8(6)$ \\
\hline \multicolumn{5}{|c|}{ Discontinuing games: } \\
\hline Intervention & $8(4)$ & $8(5)$ & $9(5)$ & $11(6)$ \\
\hline Control & $13(8)$ & $9(5)$ & $11(7)$ & $11(8)$ \\
\hline \multicolumn{5}{|c|}{$\begin{array}{l}\text { Spending playtime inside } \\
\text { school: }\end{array}$} \\
\hline Intervention & $9(5)$ & $17(10)$ & $17(9)$ & $10(6)$ \\
\hline Control & $11(7)$ & $21(13)$ & $17(11)$ & $13(9)$ \\
\hline
\end{tabular}

improvement in any measure of morbidity when the analysis was restricted to the 152 children in intervention schools who consulted their family doctor or the 58 children who had treatment for asthma introduced or changed (table II). There was no evidence of differential effects of the intervention between the sexes.

\section{Diagnosed asthma and current drugs for asthma}

Between 1988 and 1989 there was an increase in both groups in the number of children for whom parents reported a diagnosis of asthma (from 61 to 81 in children in intervention schools and from 69 to 80 in children in control schools). There was a similar increase in use of drugs, both for $\beta$ agonists (from 35 to 44 and from 42 to 62 respectively), and of prophylaxis (from 2 to 23 and from 2 to 22 ). None of these changes differed significantly between the two groups.

\section{School practices and teachers' knowledge}

Head teachers reported a slight increase in the number of children taking inhalers to school in the intervention year compared with the previous year (table IV). Class teachers reported similar figures (between one and two children in each class) in 1989. At the end of the study children in intervention schools were more likely to keep their inhalers with them during school hours than those in control schools $(42 \%$ $v 34 \%, \mathrm{p}<0.05)$, and according to their class teacher were more likely to use their inhaler before games $(44 \%$ $v 38 \%, \mathrm{p}<0.5)$. This was corroborated by parents (table V) and by head teachers, who confirmed that the schools were allowing more children access to their inhalers (that is, all children or older children were allowed to keep inhalers with them at all times) and that more intervention schools had introduced a central list of asthmatic children (table IV).

TABLE IV-Management of asthma in schools (from head teacher questionnaires)

\begin{tabular}{|c|c|c|c|c|c|}
\hline & \multicolumn{2}{|c|}{$\begin{array}{l}\text { Intervention } \\
\text { schools }\end{array}$} & \multicolumn{2}{|c|}{$\begin{array}{l}\text { Control } \\
\text { schools }\end{array}$} & \multirow[b]{2}{*}{ p Valuex } \\
\hline & 1988 & 1989 & 1988 & 1989 & \\
\hline \multicolumn{6}{|l|}{$\begin{array}{l}\text { No of children with an inhaler in } \\
\text { school }\end{array}$} \\
\hline $\begin{array}{l}\text { No of schools where all children } \\
\text { kept own inhalers }\end{array}$ & 18 & 35 & 21 & 18 & $<0 \cdot 001$ \\
\hline $\begin{array}{l}\text { No of 'schools with central list of } \\
\text { asthmatic children }\end{array}$ & 14 & 25 & 22 & 24 & $<0.01$ \\
\hline $\begin{array}{l}\text { No of schools where parent usually/ } \\
\text { always indicated on admission } \\
\text { form if child had asthma }\end{array}$ & 38 & 41 & 42 & 43 & NS \\
\hline $\begin{array}{l}\text { No of schools where parent usually/ } \\
\text { always informed school of asthma } \\
\text { drugs to be taken in school }\end{array}$ & 42 & 46 & 48 & 47 & NS \\
\hline for asthma drugs & 18 & 24 & 15 & 21 & NS \\
\hline
\end{tabular}

^Based on $\chi_{*}^{2}$ analysis for difference in change between intervention and control schools.

TABLE $\mathrm{V}-$ Children's access to drugs for asthma in school (from parent reports, 1989^). Figures are numbers (percentages) of children

\begin{tabular}{|c|c|c|c|}
\hline & $\begin{array}{l}\text { Intervention } \\
\text { schools } \\
\text { No }(\%)\end{array}$ & $\begin{array}{l}\text { Control } \\
\text { schools } \\
\text { No }(\%)\end{array}$ & $\mathrm{p}$ Valuet \\
\hline $\begin{array}{l}\text { Children who were currently taking } \\
\text { asthma drugs to school }\end{array}$ & 271 & 205 & \\
\hline Children who kept inhalers with them & $131(48)$ & $57(28)$ & $<0.0001$ \\
\hline $\begin{array}{l}\text { Children whose parents preferred } \\
\text { them to keep their inhalers }\end{array}$ & $173(64)$ & $116(57)$ & NS \\
\hline $\begin{array}{l}\text { Children to whom advice was given in } \\
\text { school to use inhaler before games } \\
\text { lessons }\end{array}$ & $156(58)$ & $106(52)$ & NS \\
\hline $\begin{array}{l}\text { Children who used inhaler before } \\
\text { games lessons }\end{array}$ & $111(41)$ & $56(27)$ & $<0.003$ \\
\hline $\begin{array}{l}\text { Children whose parents sent written } \\
\text { instructions to school about asthma } \\
\text { treatment }\end{array}$ & $87(32)$ & $54(26)$ & NS \\
\hline
\end{tabular}

At the end of the study teachers in intervention schools were more likely to feel adequately prepared to supervise a child with asthma than teachers from control schools (135/241 (56\%) v 47/276 (17\%)). Those who had attended the talk given by the school nurse on asthma gave more correct responses to a multiple choice test on asthma $(\mathrm{p}<0 \cdot 001)$.

\section{Teacher evaluation of school nurse talk}

Of the 241 teachers from intervention schools who returned a questionnaire, 172 had attended a nurse teaching session on asthma. Most welcomed the teaching session and thought it should be repeated at least once a year.

\section{Discussion}

The intervention assessed in this study was designed as a practical response to reports that underdiagnosis and undertreatment of asthma is an important problem in schoolchildren..$^{1-9}$ Our objective was to improve the diagnosis and management of children with potentially treatable morbidity by using resources that are currently ávailable to most schools, so that, if successful, the intervention could be implemented widely. 
We found that $67 \%$ of parents responded to the advice given to the intervention group and took their child to their general practitioner for assessment. Treatment for asthma was introduced or changed as a result of this assessment in a third of these children. The teaching on asthma delivered by school nurses to schoolteachers was well received and led to measurable improvements in the practical management of asthma at school. As in previous intervention studies, ${ }^{47}$ parent reported absence from school because of asthma fell substantially in the intervention group over the study year. A similar fall, however, also occurred in the control group, and there was no significant difference in either this or any other measure of morbidity between the two groups. We might have been able to achieve greater compliance from parents with the general practitioners' assessments by more intensive coercion but we specifically wished to assess the effect of an intervention that was within the resources available to most schools. We did, however, assess whether the intervention was more effective in those who complied fully with it by looking at the subgroups of children who attended the general practitioner, or in whom the general practitioner instigated some change in treatment. We found no evidence that the intervention was appreciably more effective in these groups.

Some of the fall in parent reported school absence over the study period was probably due to initial overreporting by parents. In the year before the intervention parent reported school absence because of wheezing accounted for about half of the total absence recorded by schools. However, the reductions in parent reported asthma that subsequently occurred in both groups during the study period were not accompanied by equivalent falls in school registered absence. The simplest explanation for this discrepancy is that parents initially overestimated time lost from school because of wheezing. The apparent effectiveness of previous interventions ${ }^{47}$ may therefore be attributable in part to similar overreporting by parents at the outset of the study, and this point emphasises the need for a control group in studies such as this.

Although the visit to the general practitioner led to a new diagnosis of asthma in 39 children and a change in treatment in 58 , similar changes also occurred in children in control schools. The large increase in treatment for asthma in children in control schools during the study may have been a study effect, possibly arising from increased parental awareness of respiratory problems as a result of completing the initial questionnaire. The general practitioners may also have become more aware of asthma in children as a result of this study and our previous study and have been more inclined to start prophylactic treatment. We are not aware of any other local external factors in Nottingham during the study period that could account for the change in both groups. Alternatively our findings may have been due to a more general trend of increased awareness of asthma and its associated morbidity, to which our study contributed relatively little. There is evidence for a fairly pronounced temporal increase in the use of asthma as a diagnostic label for wheezing illness in Nottingham primary school children between 1985 and 1998, ${ }^{11}$ which is likely to have continued and to have affected both groups during the study period.

The finding that our intervention was unsuccessful in terms of affecting the primary end points of change in school absence and time lost from sport and other school activities is unlikely to be due to a lack of statistical power as our study was sufficiently large to detect a difference of two days' school absence between the two groups. We conclude that our intervention programme did not make an appreciable difference to morbidity associated with asthma when assessed as time lost from school or games lessons. This is probably in part because the extent of underdiagnosis and undertreatment in 1988 was less than that shown previously, ${ }^{3}$ and the capacity for improvement was therefore reduced. The prevalence of diagnosed asthma in Nottingham schoolchildren in 1988 was $8 \cdot 9 \%,{ }^{11}$ which is considerably higher than the $1 \cdot 2 \%$ recorded in Newcastle in $1979 .{ }^{3}$ Some of this increase might have been due to a true increase in the prevalence or severity of asthma, ${ }^{16-20}$ but as the prevalence of wheezing has changed relatively little in recent years ${ }^{101120}$ most of the change is likely to have been due to greater recognition and labelling of wheezy children as a result of the early studies. ${ }^{2.5}$ The amount of time lost from school because of wheezing was also considerably less in our study than in the two previous intervention studies, ${ }^{47}$ again suggesting that asthma is now causing less morbidity in asthmatic children.

The teacher education programme was successful in increasing teachers' knowledge and confidence and in improving certain aspects of management of asthma in schools-for example, by having a central list of asthmatic children, allowing better access to inhalers, and enabling inhalers to be used more often before sport. Benefits from health education are difficult to evaluate objectively as changes in knowledge may take time to translate into detectable changes in behaviour. The participation of school nurses should enable continuing support and advice to be available to teachers, with the potential for further education on a regular basis.

Although we were unable to show benefit from our intervention in this study, this finding may apply only in the context of relatively high prevalences of diagnosed asthma and relatively low levels of school absence because of the disease. The intervention may be more effective in areas where the prevalence of diagnosed asthma is lower. It is easy to introduce a screening questionnaire for asthma for all children on school entry, and this should ensure that schools are aware of children with asthma and those taking drugs for asthma. School nurses can deliver teaching programmes that are effective in improving some aspects of management of asthma in schools.

We thank the Asthma Research Council for funding this study, Allen and Hanburys for providing the video film, and Boehringer Ingelheim for help with educational materials. We also acknowledge valuable advice from Professor A D Milner, Dr E J Hiller, Dr D Jenkinson, Dr C Pullen, Dr M Hills, Professor R Madeley, and Dr J Pearson. We thank Mr A Fox and Mrs A Kemp for their permission for this study. We are indebted to all head teachers, school secretaries, and class teachers and to the Nottingham general practitioners who participated in the project. Finally, we thank all the parents and children who took part.

1 Speight ANP. Is childhood asthma being underdiagnosed and undertreated? BMF 1978;ii:331-2.

2 Anderson HR, Cooper JS, Bailey PA, Palmer JC. Influence of morbidity, illness label, and social, family, and health service factors on drug treatmen of childhood asthma. Lancet 1981;ii:1030-2.

3 Lee DA, Winslow NR, Speight AN, Hey EN. Prevalence and spectrum of asthma in childhood. BMJ 1983;286:1256-8. asthma in childhood. BMf 1983;286:1256-8.
4 Speight AN, Lee DA, Hay EN. Underdiagnosis and undertreatment of asthma
in childhood. BMF 1983;286:1253-7.

5 Anderson HR, Bailey PA, Cooper JC, West S. Morbidity and school absence caused by asthma and wheezing illness. Arch Dis Child 1983;58:777-84.

caused by asthma and wheezing illness. Arch Dis Child 1983;58:777-84.
6 Levy M, Bell L. General practice audit of asthma in children. BMJ 1984;289:1115-6.

7 Colver AF. Community campaign against asthma. Arch Dis Child 1984;59: 449-52.

8 Heijne den Bak J. Prevalence and management of asthma in children under 16 in one practice. $B M F$ 1986;292:175-6.

9 Coughlin SP. Sport and the asthmatic child: a study of exercise-induced asthma and the resultant handicap. I $R$ Coll Gen Pract 1988;38:253-5.

10 Hill RA, Standen PJ, Tattersfield AE. Asthma, wheezing and school absence in primary schools. Arch Dis Child 1989;64:246-51.

11 Hill RA, Williams J, Tattersfield AE, Britton JR. Change in use of asthma as a diagnostic label for wheezing illness in schoolchildren. BMJ 1989;299:898. 12 Hill RA, Britton JR, Tattersfield AE. Management of asthma in schools. Arch Dis Child 1987;624:114-5.

13 Storr J, Barrell E, Lenney W. Asthma in primary schools. BMF 1987;295: 251-2.

14 Statistical Package for the Social Sciences. SPSSX user's guide. New York: McGraw Hill, 1983:601-21. 
15 Numerical Algorithms Group. Generalised linear interactive modelling system. Oxford: Royal Statiscical Society, 1986. (Release 3.77.)

16 Anderson HR. Increase in hospital admissions for childhood asthma: trends in referral, severity and readmissions from 1970 to 1985 in a health region of the UK. Thorax 1989;44:614-9.

17 Burr ML, Butland BK, King S, Vaughan-Williams E. Changes in asthma prevalence: two surveys 15 years apart. Arch Dis Child 1989;64:1452-6.

18 Burney PGJ, Chinn S, Rona RJ. Has the prevalence of asthma increased in children? Evidence from the national study of health and growth 1973-86. BMF 1990;300:1306-10.

19 Haahtela T, Lindholm H, Biorksten F, Koskenvuo K, Laitinen LA Prevalence of asthma in Finnish young men. BMF 1990;301:266-8. 20 Anderson HR. Is the prevalence of asthma changing? Arch Dis Child 1989;64:172-5.

\section{Surveillance of antibody to rubella virus in Grampian: closing the immunity gap}

M I K B Berkeley, M A J Moffat, D Russell

\begin{abstract}
Objectives - To identify causes for the continuing deficit of rubella immunity in women of childbearing age with a view to further reducing the risk of the congenital rubella syndrome.
\end{abstract}

Design-A questionnaire was sent to the general practitioner and a laboratory follow up study conducted in a one year cohort of women found on screening to have inadequate protection against rubella.

Setting-Virus laboratory of the department of medical microbiology, Aberdeen, serving the health board areas of Grampian, Orkney, and Shetland.

Patients-239 women whose concentration of antibodies to rubella virus was either absent or below standard (15000 IU/l) and whose general practitioner could be contacted to supply a history of infection, immunisation, pregnancy, and antibody testing.

Main outcome measures-Whether rubella vaccination was given and whether those vaccinated were tested for seroconversion.

Results-Only $122(55 \%)$ of the women for whom information was available received the recommended vaccine; only $74(61 \%)$ of these were tested for seroconversion. Oversight was the reason given for not vaccinating $64(65 \%)$ of the women who remained at risk. Women who were pregnant when tested were significantly less likely to receive vaccine (odds ratio 3.36) than women who were not pregnant, and even if vaccinated were less likely to have a follow up antibody test (odds ratio 1.94).

Conclusion-Once women are identified as being unprotected against rubella they are often overlooked and not vaccinated. Prompting mechanisms aimed at general practitioners, such as the one recently set up in Grampian, should reduce the immunity gap and help to eradicate rubella in pregnancy.

Department of Public Health, University of Aberdeen, University Medical Buildings, Aberdeen AB9 2ZD M I K B Berkeley, FFPHM, teaching fellow

D Russell, MA, statistician

Department of Medical Microbiology

M A J Moffat, PHD, senior lecturer

Correspondence to:

Dr Moffat.

$B M 7$ 1991;303:1174-6

\section{Introduction}

The aim of the selective immunisation policy for schoolgirls and women was to control and ultimately eliminate rubella in pregnancy. ${ }^{2}$ As a result, the susceptibility of antenatal women to rubella has declined to less than $2 \%$ in most areas of the United Kingdom. ${ }^{3}$ Further reduction is thought to be unlikely owing to women missing vaccination or the failure to mount or maintain a detectable antibody response. ${ }^{4}$ This means that in Grampian, for example, at least 100 women each year continue to be at risk of contracting rubella in pregnancy. The measles, mumps, and rubella vaccination programme should reduce the chance of infection, ${ }^{5}$ but increased efforts must still be made to vaccinate susceptible women if congenital rubella is to be eradicated from the United Kingdom.
We investigated a group of women identified in 1987 as having rubella antibody levels below $15000 \mathrm{IU} / 1$ to find out why they were still susceptible to rubella and what action had been taken as a result of the laboratory report.

\section{Subjects and methods}

During 1987 blood samples from 8357 women from general practice, hospital, and occupational health clinics in Grampian, Orkney, and Shetland were screened for antibody to rubella virus at the virus laboratory of the University of Aberdeen by the single radial haemolysis method. In all, 149 women were seronegative (no antibody zone on testing) and 108 had equivocal results (antibody was present, but less than the Public Health Laboratory Service's standard of $15 \mathrm{IU} / \mathrm{ml}$ ), giving a total of 257 "unprotected" women. All women with equivocal results were included in the unprotected group to ensure that vaccine was recommended in the laboratory report for all those with doubtful levels. The report also carried a recommendation for a follow up antibody test six weeks after vaccination (if this test was negative a further sample was requested to allow for delayed antibody response).

Of the 257 unprotected women, 239 were available for study. A questionnaire was sent to the general practitioner of each woman to obtain demographic and rubella related data.

\section{Results}

Of the 239 questionnaires sent to general practitioners, 233 were returned, giving a response rate of $97 \%(91 \%$ of all unprotected women identified in 1987). Data from the laboratory reports were available for the six women whose questionnaire was not returned and for a further 12 women whose questionnaire was returned incomplete. Table I gives the sources of the blood samples with reasons for testing as stated on the laboratory request forms. Eleven women

TABLE I-Source of blood samples and reason for testing in women with rubella antibody level $<15000$ IU/l

\begin{tabular}{llr}
\hline Source & \multicolumn{1}{c}{ Reason } & $\begin{array}{c}\text { No of } \\
\text { samples }\end{array}$ \\
\hline \multirow{5}{*}{ General practitioner } & Routine & 52 \\
& Antenatal-routine & 114 \\
Antenatal-rubella contact & 1 \\
Suspected rubella infection & 7 \\
Rubella in pregnancy & 2 \\
Infertility & 1 \\
Hospital & Pregnancy & 21 \\
Routine screening & 2 \\
Occupational health service & Sermination of pregnancy & 17 \\
\hline \multirow{2}{*}{ Total } & Screening test & 13 \\
& & 9 \\
\hline
\end{tabular}

